\title{
Professor Dr. Marcello Caetano Recebido Solenemente na Academia.
}

A 20 de junho de 1966 no salão nobre desta Faculdade, reuniu-se a Congregação dos Professôres em sessão solene presidida pelo Magnífico Reitor da Universidade de São Paulo, Prof. Dr. Luís Antônio da Gama e Silva, para recepcionar ilustre catedrático da Universidade de Lisboa, Professor Doutor Marcello Caetano.

Introduzido no recinto foi o visitante saudado pelo Professor Dr. Alfredo Buzaid, Diretor da Faculdade, cujas palavras, repassadas de admiração e solidariedade cultural, analisaram-lhe a personalidade e obra.

Agradecendo a recepção e as palavras de boas vindas, Professor Marcello Caetano evocou as "gloriosas tradições" desta casa e as relações culturais entre a Universidade de Lisboa e a de São Paulo. A seguir proferiu conferência desenvolvendo o tema Tendências Européias do Direito Administrativo, que se publica na sessão de Doutrina dêste fascículo

\section{Discurso de Saudação do Prof. Dr. Alfredo Buzaid.}

Esta Faculdade se engalana para festejar com entusiasmo vossa visita e anseia por ouvir-vos a palavra eloqüente, erudita e autorizada. As portas desta Casa sempre se descerraram para ouvir os maiores mestres europeus e americanos numa autêntica política universitária de intercâmbio cultural. No entanto, a vossa conferência tem para nós um significado mais particular. É a mensagem de uma nação irmã, a que estamos vinculados pelo sangue, 
pela vocação religiosa e pelo destino histórico. Enquanto os outros professôres realizam um encontro puramente intelectual, a vossa presença é um reencontro de duas nacionalidades, a que a história traçou um fadário comum.

Atravessando os humbrais dêste templo, percebestes naturalmente que não sois um mestre estranho senão um sacerdote da mesma companhia, falando o mesmo idioma, professando o mesmo credo e sonhando as mesmas realidades. Viestes de um país, tão pequenino em seu território, quão grande na luminosa trajetória que a Providência lhe reservou e contemplais outro país, que tem o corpo plantado na América e a alma importada da Europa. Éste país é o Brasil, uma criação do espirito português, que não se limitou a descobrir terras e propagar nelas a fé católica.

Reponta o gênio lusitano em dois momentos capitais da história de nossa Pátria. O primeiro foi ao talhar a organização administrativa do país em capitanias de juro e herdade, que evoluiram nas provincias do Império e no atual sistema federativo. Revela-se aí a intuição de que o país não podia viver e prosperar sob as rédeas de uma estreita e acanhada centralização. O segundo foi a epopéia do bandeirismo na conquista do sertão impermeável. Os antigos portuguêses, de sapatão de couro cru e chapeirão desabado, compreenderam que a civilização do litoral faria perder o território imenso, que estava no seio do continente. Atraídos pela voz misteriosa, que ecoou dos picos das ibiturunas, encetaram a marcha para o Oeste, só se detendo nos cimos da cordilheira, de onde avistaram o oceano pacífico. Estava roto o Tratado de Tordesilhas. Nasceu o Brasil, quando essa raça admirável de desbravadores acordou as montanhas, pontilhou as fronteiras da Pátria e rasgou o imenso território em tôdas as direções.

Malgrado a diversidade de sua formação geológica, de seu sistema orográfico, do curso de seus rios, a pátria 
raiou una e indivisível, sob o tropel das marchas, os tiros de bacamarte, os silvos das flexas, o canto dos pássaros e o rugido das feras. Essa raça de sertanistas fundiu uma alma telúrica, que tinha o fascínio de dois infinitos: o mar e o sertão.

Vós pertenceis a êsse povo, cujos ancestrais evidenciaram o mais acendrado tino político e administrativo. E a centelha, que iluminou os séculos passados, reluz agora nas vossas obras e na vossa vida. Muito moço, a vossa vocação para os estudos jurídicos se concentrou no direito financeiro e publicastes em 1931, como dissertação ao doutoramento, A Depreciação da Moeda Depois da Guerra: Com êste valioso estudo, encetastes a carreira universitária. Tal bruxoleio dava a idéia de que a vossa paixão era o direito financeiro.

Esta impressão foi logo desfeita ao demonstrardes que o vosso espírito, insaciável de saber, não tolerava limitações. Logo em 1932 vinha a lume Do Poder Disciplinar no Direito Administrativo Português, onde o jovem professor, sob a influência de Magalhães Collaço, empreendia a revisão científica dêsse ramo da ciência jurídica, conciliando o método dogmático com o exame-crítico das fontes à luz da história, da política e da filosofia. O vosso Manual de Direito Administrativo, do qual se tiram várias edições, obedece rigorosamente a essa orientação renovadora, que se insurge contra o positivismo jurídico árido, medíocre e prosáico.

De par com trabalhos menores, sai o Curso de Ciência Política e Direito Constitucional, que constitui um dos cimos da cultura portuguêsa e a auréola que o cobre já transcendeu as fronteiras pelo vigor e originalidade das idéias. $O$ historiador rivaliza com o publicista. Aquêle mergulha as investigações, nas profundezas dos séculos, revendo e criticando documentos, compondo a físionomia de cada período e descrevendo os episódios com fluência, graça e louçania de estilo. O publicista é o geômetra das 
construções arquitetônicas, cujo sistema guarda a pureza dos conceitos e afirma a existência de um direito natural eterno, a que devem subpor-se os monumentos jurídicos contingentes e temporais.

A política, vós a cultivais não apenas nas reflexões do gabinete, nas discussões meramente teóricas dos princípios gerais ou na verificação das grandes experiências humanas. Ocupastes, com a visão de estadista, os mais altos postos da administração pública. Assim é a política. Ainda quando a desamamos, raramente conseguimos dela libertar-nos, porque, no fundo de tôda malquerença, quase sempre se oculta uma parcela de afeição ou pelo menos de estima.

Na vossa derradeira obra, denominada Páginas Inoportunas, reunistes um conjunto de conferências, discursos e estudos. No prefácio transmitis a angústia do intelectual, que se move com dificuldade no mundo moderno. $O$ intelectual já não encontra lazer para as suas meditações e consegue, a custo, recolher-se, a fim de refletir, falecendo-lhe o tempo necessário para escrever e comunicar o resultado de suas locubrações. Vós não escreveis por ofício mecânico. Tendes sempre uma mensagem a transmitir. Afortunadamente pudestes ordenar nesse livro idéias e reflexões que, sem o registro que as conserva, cairiam no esquecimento que sepulta os longos monólogos e os conflitos interiores.

Permiti-me, senhor professor, que para encerrar faça uma observação. As grandes obras hão de ser lidas em suas linhas e em suas entrelinhas, a fim de surpreender a intenção do escritor. Vós apusestes dois apêndices no Curso de Ciência Politica e Direito Constitucional. No fim do primeiro volume, a Declaração dos Direitos do Homem; no fim do segundo, a Constituição Portuguêsa.

A publicação daquêle documento define nitidamente as tendências do vosso espírito. Vós acreditais que êle exprime os anseios da humanidade há vários séculos. A 
experiência dos povos civilizados foi provando, desde a Magna Charta Libertatum até a Declaração Universal de 1948, que há direitos do homem anteriores e superiores ao Estado, que as constituições não podem desconhecer. Mas, por outro lado, vós percebestes claramente que a Constituição Portuguêsa, ao instituir o direito corporativo, fundiu as aspirações do povo. A experiência universal, tantas vêzes lembrada por politicos e estadistas (MoNTAIGNE, Ensáios, I, pág. 49), tem mostrado que o que se deve dar a um povo não é a melhor constituição, mas a melhor para êle, ou, em outras palavras, não convém darlha, mas sim deixar que êle a encontre sòzinho.

A vossa fina intuição, inserindo os dois apêndices, revela a visão nacional do estadista e a visão universal do jurista. 